\title{
Colonial Legal Reasoning in the Post-Colonial African State: A Critique and a Defense of the Argument from African Metaphysical Epistemology ${ }^{1}$
}

\author{
Ronald Olufemi Badru \\ Department of Politics and International Relations \\ Lead City University, Ibadan, Nigeria \\ femmydamak@gmail.com or femmydamak@yhaoo.com \\ and \\ Tayo Raymond Eegunlusi \\ General Studies Department \\ Federal University of Technology, Akure, Nigeria \\ kingadetayo@yahoo.com
}

DOI: $\underline{\text { http://dx.doi.org/10.4314/tp.v7i2.3 }}$

Thought and Practice: A Journal of the Philosophical Association of Kenya (PAK)

New Series, Vol.7 No.2, December 2015, pp.11-39

thoughtandpractice@gmail.com

http://ajol.info/index.php/tp

ISSN: 2076-7714

\footnotetext{
${ }^{1}$ The authors profusely thank the reviewers and the Editor-in-Chief of Thought and Practice for their helpful comments on the earlier draft of this article.
} 


\begin{abstract}
This article focuses on legal reasoning and legal epistemology within the African context. It examines the system of legal justice in post-colonial Africa and submits that because of the colonial legacy, post-colonial African legal reasoning is methodologically founded on empiricism and positivism. It avers that despite its merit of scientific objectivity, such legal reasoning is largely incapable of addressing offences committed through the manipulation of metaphysical realities or other forms of covert criminalities and wrongdoing. Consequently, the article proposes that the methodology of African metaphysical epistemology be adopted to complement the colonial methodology of legal reasoning in Africa, as it has the advantageous result of helping in the search for truth concerning such offences, thereby promoting the delivery of effective legal justice, and thus contributing significantly to the development of a balanced and reliable justice system in contemporary African societies. The methods of critical analysis, reflective argumentation and oral interview were adopted to pursue the goals of the study.
\end{abstract}

\title{
Keywords
}

Africa, Argument, Legal Epistemology, Legal Reasoning, Metaphysics

\section{Glossary}

Epistemology: a branch of philosophy which focuses on a critical and systematic investigation of the nature, sources and quality of knowledge. It is also referred to as the theory of knowledge.

Metaphysics: a branch of philosophy which focuses on a critical and systematic study of the nature and basic principles of reality.

African metaphysical epistemology: a sub-branch of African philosophy which focuses on the spiritual modes of knowing empirically hidden facts about the present or the future world. 
Empiricism: an epistemic theory which emphasizes that the ultimate source of human knowledge is the sense experience of the human person. Some of the well known empiricists in Western philosophy are Aristotle, John Locke, David Hume and George Berkeley. The opposite epistemic theory is rationalism, which emphasizes that the ultimate source of human knowledge is human reason. Some of the well known rationalists in Western philosophy are Plato, Rene Descartes, Benedict Spinoza, and Gottfried Wilhelm Leibniz.

Positivism: a position in the philosophy of science which holds that it is only an empirically (a scientifically) verifiable entity that should be recognized as knowable or properly constituting an existent. As a legal variant of this position, legal positivism claims that laws or legal rules are only (or should only be) validly drawn from a social fact - a socially constituted authority, such as the legislature, or any other body or institution that has been relevantly empowered to make law-like rules in society.

Ontology: a sub-branch of metaphysics (see above) which focuses on a philosophical study of the nature and qualities of being or what is.

Cosmology: a sub-branch of metaphysics (see above) which focuses on an investigation of the origin and nature (or totality) of the universe (all that exists). The term is also used to refer to a philosophical study of the totality of the world-view or system of beliefs of a people (as distinguished from that of another group of people). 


\section{Introduction}

There is good reason to argue that in order to establish and sustain good governance and a stable society on the whole, a state needs a balanced and efficient justice system. Perhaps a fundamental aspect of a system of legal justice, apart from the requisite institutions and personnel, is the legal reasoning, roughly taken to be the reasoning process employed by the actors involved in the dispensing of legal justice. For a very long time, the Western mode of legal reasoning has been founded on what one could reasonably call the principles of empiricism and positivism. This roughly means that before a valid legal pronouncement is made on any criminal legal issue, for example, between $\mathrm{X}$ and $\mathrm{Y}$, at least two principles must be followed. First, there should be a physically demonstrable causal connection between the injury suffered by the victim and the action of the offender (the empiricist angle). Second, the law being applied should be ostensibly spelt out in a known document and laid out by a known sovereign. In any contemporary society, the sovereign may be regarded as a constitutionally constituted authority charged with the responsibility of law-making (the legislature); judges' pronouncements in celebrated cases decided in the past (stare decisis), and so on (the positivist angle). This legal reasoning has been extended to other non-Western regions of the world through Western colonisation.

The Western mode of legal reasoning has been dominant within the system of legal justice in post-colonial Africa because of its colonial past. However, this article argues that this mode of legal reasoning has been largely ineffective in dealing with metaphysically induced criminalities and other forms of covert wrongdoing that are now rampant in contemporary African society. Consequently, the article recommends that in order to enhance truth finding about metaphysically induced criminalities and other forms of covert wrongdoing, the methodology of African metaphysical epistemology be adopted to complement the Western mode of legal reasoning before legal justice is dispensed. It is only then that post-colonial African societies could boast of effective and balanced legal justice systems, systems that duly recognise the peculiarities that follow from the commitment to the thinking of duality of reality which permeates African cosmology and ontology. 
The article is divided into six sections. Section I introduces the discussion; Section II undertakes some preliminary conceptual clarifications; Section III examines the historical background to the empiricist and positivist basis of the dominant legal reasoning in the post-colonial African state; Section IV discusses the shortcomings of the dominant legal reasoning in post-colonial Africa; Section V suggests a way to circumvent the weaknesses of the dominant legal reasoning in post-colonial Africa through the adoption of the methodology of African metaphysical epistemology; Section VI is a summary and conclusion.

\section{Preliminary Conceptual Clarifications}

We consider it apposite to start the present work with a good understanding of two principal concepts, namely, legal reasoning and African metaphysical epistemology.

\section{(a) Legal reasoning}

According to Harris $(1997,211,212)$, the concept of legal reasoning lends itself to diverse interpretations, depending on who the interpreter is. For solicitors and barristers, legal reasoning is all about prediction; advocates take it to be concerned with persuasion; judges ostensibly regard it as all about justification; legal text writers may engage in it as prediction and persuasion. Despite his presentation of the divergent views, Harris still admits that most writers usually assume the object of legal reasoning to be justification in the familiar sense of supporting the right answer, that is, providing reasons to show that a course of action is legally supported or why it ought to be legally supported (Harris 1997, 212). In addition, Harris himself proceeds from the assumption that justification is the primary function of legal reasoning upon which prediction and persuasion are parasitic (Harris 1997, 212). Furthermore, a look at the nature of the institution of law in the scientific-oriented Western world should convince us that the institution is usually understood in the empiricist and positivist sense. Thus, reasons offered in support of a course of action in law are also founded on this empiricist and positivist tradition.

In the present article, legal reasoning is to be employed in a specific sense and within the confines of criminal justice. In this contextually specific sense, legal reasoning is 
understood to be a cognitive process of moving from the level of the so-called physical evidence (however this is interpreted) to the level of affirmation of a person as a crime suspect (in the case of police arrest, detention and prosecution), and/or a cognitive process of moving from the level of the so-called physical evidence (again however this is interpreted) to the level of pronouncement of a judgment in a law court (in the case of the judge) - a judgment that is claimed to have been derived from the interrogation of the physical evidence advanced in the dispensation of legal justice. Thus understood, legal reasoning is partly logical and partly epistemic. It is logical in the sense that it is a sub-set of coherent reasoning (logic being all about reasoning, inductive or deductive). It is inductive when it applies the fact(s) of past decided cases to the present case; it is deductive when it applies general legal rules to the present case. It is epistemic in the sense that it is a deliberate exercise in erroravoiding in the systematic process of truth-seeking in the dispensation of legal justice, truth being one of the features of the traditional Western account of knowledge, from the era of Plato.

\section{(b) African metaphysical epistemology}

As a phrase, African metaphysical epistemology is a lexical conjugation of metaphysics and epistemology within the broad fold of African philosophy. Contextually, African metaphysical epistemology refers to specific methodologies of truth-seeking (or knowledge-acquisition) that are widely employed in traditional African societies. The objects of these methodologies are trans-empirical or extrasensible reality and other forms of covert, though sensible, reality.

\section{Philosophical Historiography of the Colonial Legal Reasoning in the Post-Colonial African State}

The development of the dominant empiricist and positivist mode of legal reasoning in Africa could be traced to both remote and immediate sources. The remote source is connected to the emergence of the Comtean positivism as well as the command theory of law founded by Jeremy Bentham (1748-1832) and popularized by his disciple, John Austin (1790-1859). The immediate cause of empiricism and positivism in the 
dominant legal reasoning in post-colonial Africa is located in its colonial past. The two events are briefly examined below.

\section{(a) Comtean Positivism and Legal Positivism}

Comtean positivism, otherwise called social positivism, is attributed to the French sociologist and philosopher Auguste Comte (1798-1857), who developed what he referred to as "a science of society", now commonly referred to as "sociology", built upon a scientifically oriented philosophy, positive philosophy or positivism (Stumpf 1994, 356). Specifically, Comte came up with the law of the three stages to account for the development of the human explanations of natural phenomena in their environment. For Comte $(2000,27)$, "each branch of our knowledge passes successfully through three theoretical conditions: the Theological, or fictitious; the Metaphysical, or abstract; and the Scientific, or positive.” He explains further:

In the theological state, the human mind, seeking the essential nature of beings, the first and final causes (the origin and purpose of) all effects, - in short, Absolute knowledge - supposes all phenomena to be produced by the immediate action of supernatural beings. In the metaphysical state, which is only a modification of the first, the mind supposes, instead of supernatural things, abstract forces, veritable entities (that is, personified abstractions), inherent in all beings, and capable of producing all phenomena. What is called the explanation of phenomena is, in this stage, a mere reference of each to its proper entity ... In the final, the positive state, the mind has given over the vain search after Absolute notions, the origin and destination of the universe, ... and applies itself to the study of their laws, - that is, their invariable relations of succession and resemblance. Reasoning and observation, duly combined, are the means of this knowledge (Comte 2000, 28).

To argue for the superiority of the last stage in relation to the first and second, Comte $(2000,29)$ maintains that "All good intellects have repeated, since Bacon's time, that there can be no real knowledge but that which is based on observed facts." Stated differently, Comte holds that the highest and most advanced form of knowledge is that derived from, and confirmed by, human observation, but not by any theological or metaphysical speculation.

It was this scientism of Comte that also extended to the realm of legal theory and practice in Western societies, and this engendered the whole idea of legal positivism. 
Nevertheless, it is difficult to precisely conceptualise legal positivism. Waluchow graphically notes the difficulty involved as follows:

Despite its profound influence on the development of legal theory and (arguably) legal practice, and despite the considerable efforts of some theorists to undermine that influence, controversy and confusion abound concerning just what it is that legal positivists are supposed to be saying (Waluchow 1998, 2).

Similarly, Greenawalt $(1996,19)$ states that legal positivism as a label is more of a rhetorical force, since it does not genuinely clarify serious positions. According to him, theorists should endeavour to carefully explain just how they are using the label.

Perhaps a starting point towards understanding what legal positivism is all about, at least for the purposes of this article, is to grasp what positivism itself is. Raymond Wacks $(2006,18)$ explains that "The term 'positivism' derives from the Latin positum, which refers to the law as it is laid down or posited." He states further that "the core of legal positivism is the view that the validity of any law can be traced to an objectively verifiable source" (Wacks 2006, 18). Thus one could say that positivism essentially emphasizes empiricism, secularity and sociality. Derivatively, one could attempt to define legal positivism as expressive of at least two things, namely, (1) that law creation and annulment are, and should be, acts of specific human beings in society (the thesis of sociality, or society-responsiveness), and (2) that law, therefore, is independent of, and separate from, morality and similar normative systems of theology and metaphysics (the thesis of separability, or nonmoral responsiveness). One popular version of this positivist approach to legal theory is the command theory of law, which has been largely dominated by the thinking of classical legal philosophers Jeremy Bentham and John Austin. According to Bentham, a law may be defined as follows:

An assemblage of signs declarative of a volition conceived or adopted by the sovereign in a state, concerning the conduct to be observed in a certain case by a person or class of persons, who in the case in question are or are supposed to be subject to his power; such volition trusting for its accomplishment to the expectation of certain events which it is intended such declaration should, upon occasion, be a means of bringing to pass, and the prospect of which it is intended such acts as a motive upon those whose conduct is in question (Bentham 1970, 1).

In this conception of law, at least three features stand out: (1) law is strictly the imperative of the sovereign; (2) the sovereign is empirically or socially determinate; 
(3) there should be obedience to the imperative of the empirically or socially determinate sovereign by a person whose conduct is regulated by the imperative.

John Austin (1954), a disciple of Jeremy Bentham, also has a similar thinking about the nature of law:

Positive laws, or laws strictly so called, are established directly or immediately by authors of three kinds:-by monarchs, or sovereign bodies, as supreme political superiors: by men in a state of subjection, as subordinate political superiors: by subjects, as private persons, in pursuance of legal rights. But every positive law, or every law strictly so called, is a direct or circuitous command of a monarch or sovereign number ... to a person or persons in a state of subjection to its author (Austin 1954, 134).

A careful consideration shows that the conception of law by Austin also replicates the features inferred earlier from Bentham's reading of the nature of law as the sovereign's imperative, the definitive status of the sovereign in a state, and the required obedience of the subject of the sovereign to his imperative. It is noteworthy that the emphasis which the command theory of law places on the sovereign as lawgiver derived much from the classical work of Thomas Hobbes who formulated the Social Contract theory, in which the sovereign - the leviathan - is given more substantive powers than the people in a civil society, in order to be able to properly regulate the conduct of people so that there is no regress to the state of nature (see Hobbes 1968; Hobbes cited in Wolff 1996, 8-18). David Lyons (1984) graphically summarizes the basic claims of the sociality thesis and the separability thesis together thus:

To determine what the law is we must engage in an empirical inquiry about the relevant facts ... Social facts determine what laws exist and what they require and follow. These are a matter of objective fact. But moral judgments have no basis in fact; they simply express the attitudes that we have. So, it is impossible for law to be a function of morality. The identification and interpretation of law must be independent of moral conditions (Lyons 1984, 63-64).

The classical reading of legal positivism, as exemplified by the sociality thesis and the separability thesis, is still reflected in the positivist legal theory of contemporary times. According to Raymond Wacks, modern legal positivists usually adopt a 
considerably more sophisticated approach to the concept of law. Wacks claims that like their distinguished predecessors, the modern legal positivists also deny the relationship proposed by natural law between law and morals. He states that the claim of natural lawyers that law consists of a series of propositions derived from nature through a process of reasoning is strongly contested by legal positivists. Wacks further notes that legal positivists also often claim that there is no necessary connection between law and morals, and that the highest common factor among legal positivists is that the law as laid down should be kept separate - for the purpose of study and analysis - from the law as it ought morally to be (see Wacks 2006, 18, 18 $19,19)$.

In sum, for Wacks $(2006,18)$, the core of legal positivism is the view that the validity of any law can be traced to an objectively verifiable source. Furthermore, Julie Dickson $(2012,50)$ concurs that contemporary legal positivists are committed to the social thesis: they hold that the existence and content of the law is ultimately to be determined by reference to social facts.

The foregoing thinking, to reiterate, has played a fundamental role in legal theory and practice in the West as well as in the regions that have been colonised by the West.

\section{(b) Legal Positivism and Colonisation in Africa}

One of the legacies of colonial rule in Africa was the evolution of the empiricism and positivism in the legal theory and practice in the continent. As with other impositions from the colonialists, some justificatory argument was also offered to support the introduction of the spirit of legal positivism in Africa.

According to Idowu (2006, 34-49), the sceptical argument and the absence thesis have been employed by the colonialists to justify their imposition of legal positivism on Africans. For him "the sceptical frame in the views of the authors consists in the fact that Africans lack a conceptual and vividly correct analysis of the concepts of law" (Idowu 2006, 37). Idowu explicitly states the sceptist position further:

Significantly, the impact of this argument has been pushed further in the view that even if Africans had indigenous system of social control, 
it lacked substantially, any trace of legality, legal concepts and legal elements (Idowu 2006, 37).

Thus what the indigenous Africans allegedly lacked the colonialists had to provide.

For Idowu (2006, 37), the absence thesis is the idea that African jurisprudence does not exist in as much as there is the absence of written records. One could rationally state that the composite of the sceptist argument and the absence thesis, as rendered by Idowu, could be conveniently subsumed within the larger framework of the denial of the humanity of the negroid race by some prominent Western philosophers and social scientists. For example, the English empiricist, David Hume, disparagingly views the Negroid race thus:

I am apt to suspect the Negroes and in general all the other species of men (for there are four or five different kinds) to be naturally inferior to the whites. There never was a civilized nation of any other complexion than white, nor even any individual eminent either in action or speculation. No ingenious manufacturers amongst them, no arts, no sciences ... There are Negroe slaves disposed all over Europe, of which none ever discovered any symptoms of ingenuity; tho'low people, without education, will start up amongst us, and distinguish themselves in every profession. In Jamaica indeed they talk of one Negroe as a man of parts and learning; but it is likely he is admired for very slender accomplishments, like a parrot, who speaks a few words plainly (Hume 1854, 228-229; cited in Idowu 2005, 82).

To fully support Hume's claim of the inhumanity and unproductivity of the Negroid race, Georg Wilhelm Friedrich Hegel also argues that Africa is a dark continent without history and devoid of any contribution to the development of what he calls absolute spirit in world history (Hegel 1824a; 1824b). Immanuel Kant, who preceded Hegel, had earlier stated that the original human species was white (Kant cited in Makumba 2007, 37), a view that supports the racial superiority of the Caucasian race. The foregoing forms the basis of what has been regarded as the logic of "I" superiority (see Badru 2008, 238-240) with which the colonialists' "self" interacted with the Africans' "other" as something inferior, even in the area of jurisprudence. Furthermore, this colonial legal positivism has been dominant in Africa since then. Why then does the present work set out to critically dialogue with the spirit of empiricism and positivism in the legal reasoning within the framework of the justice system of the post-colonial African state? 


\section{The Deficit of the Empiricist-Positivist Legal Reasoning in the System of Legal Justice of the Post-Colonial African State}

As noted earlier, the colonial legacy of the system of legal justice in post-colonial Africa lays emphasis on a specific form of legal reasoning which is highly empiricistpositivist. This legal reasoning stipulates that in law, a legal pronouncement is only validly made on any criminal case between $\mathrm{X}$ and $\mathrm{Y}$, for instance, when at least two principles are followed: (i) there must be a physically demonstrable causal connection between the harm suffered by the victim and the action or series of actions of the offender, or a clearly demonstrable connection between an offence committed and a suspected offender (the empiricist aspect); (ii) the law or legal rule to be applied must be clearly set out in a known document and laid out by a known sovereign. In contemporary African societies, this sovereign is regarded as a constitutionally constituted authority (such as the legislature), charged with the responsibility of lawmaking, or any other relevant authority to which the power of making legally binding rules and regulations has been delegated by the former authority, or the pronouncements of judges in celebrated cases decided in the past (stare decisis), among others (the positivist aspect). Within this context, legal reasoning is regarded as valid if the criteria are fully satisfied, and invalid if the two principles are infracted, either partially or wholly. These two principles of the Western mode of legal reasoning also manifest in the system of legal justice of other regions of the world affected and largely influenced by past Western colonisation.

In terms of merit, one cannot deny that the afore-stated empiricist-positivist legal reasoning flows from a demonstrable, laid down procedure that cannot be easily abused by any biased party. Another of its merits is that the law or legal rule that supports the legal reasoning is easily attributable to a given authority or regime, which could as well be legally questioned (and sanctioned) should it also run foul of the law or legal rule. It should be noted that these merits are highly theoretical in the sense that the base, the positive law they arise from, could still be abused in practice by a clever re-interpretation from a witty legal counsel in the process of marshalling a strong defense for his/her client(s). Once this is successfully done, the empiricistpositivist legal reasoning itself assumes a partial undertone. For example, a defense 
counsel could argue eloquently and cleverly, re-interpreting a positive legal rule in order to ensure that his/her client, though factually guilty, is ultimately acquitted (one could call this a false acquittal).

However, the empiricist-positivist legal reasoning is fallaciously reductionist: it ascribes existential significance only to empirical realities, thereby excluding the nonphysical from the realm of existence. In other words, it does not support the belief that extra-sensible or trans-empirical realities have any ontological status as well as empirically demonstrable epistemological access. To this extent, such realities are devoid of any significance in the system of legal justice. On this empiricist-positivist framework, truth-finding, which is fundamental to accurate dispensation of legal justice, should be restricted to the realm of the physical. Therefore, strictly speaking, it is in tension with the belief in the duality of reality within African cosmology and ontology - the belief that reality is composed of the physical and the non-physical. This belief is very important in truth-seeking in the endeavour to ensure an accurate and balanced legal justice system in contemporary Africa.

It is the problem of reductionism that has prevented the dominant positivist legal reasoning in Africa from making a connection between the hidden killers of important political personalities in Nigeria, for instance, and their political victims. So long as the killings are done in a state of high secrecy or through metaphysical means, negating any plausible claim of physically demonstrable causal connection between the supposed offender and the offended, they attract no legal significance in themselves and, thus, no legal punishment to the perpetrators. Consequently, legal justice is denied to the victims (if they are still alive) or to the dependents of the victims (if the victims are no longer alive). This graphically explains why the family of Chief Bola Ige, the former Attorney- General of Nigeria under the administration of Chief Olusegun Obasanjo (1999-2003), has to date been deprived of legal justice. The problem is that the dominant empiricist-positivist legal reasoning in Nigeria has largely failed to make a physically demonstrable causal connection between the supposed killer(s) (the suspected offender) and the late Chief (the victim). The actual killer(s) might have been among the initial suspects, but so long as there is no empirically demonstrable way to connect them to the killing, they go unpunished, and thus legal justice is miscarried. However, if the African metaphysical epistemology 
had been duly employed, the true killer(s) might have been identified and legally punished.

The problem of non-identification of offenders also explains why many political leaders within the contemporary African state, who have sworn to uphold the constitution in order to serve the interests of the people, soon become overly corrupt. Many of them even go unpunished. The problem is that once the empiricist-positivist legal reasoning fails to establish their guilt because they are adept at hiding their loot or clever in going about their corrupt practices, they are left alone. The message being passed across seems to be something along the lines: "Corruption in political leadership is only wrong when the people involved are not smart enough to evade the empiricist-positivist legal scrutiny." However, if the contemporary African state is serious in its endeavour to ensure a balanced and efficient legal system that is capable of tracking covert social and political criminalities as well as metaphysically induced criminalities, a complementary methodology of truth-finding in the legal system is needed. This is where the methodology of African metaphysical epistemology becomes imperative.

\section{African Metaphysical Epistemology, Truth-Finding and a Balanced System of Legal Justice in Post-Colonial Africa}

As philosophers such as Oke (2007), Idowu (2009), Balogun (2007) have argued in one way or another, a coherent legal system was not foreign to pre-colonial African societies. What seems to be largely absent in their works is how African metaphysical epistemology could be significant in ensuring accurate and balanced dispensing of legal justice in the contemporary African state. For example, Oke (2007) is only interested in showing some portion of the Ifa corpus in Yoruba cosmology that could be employed to argue against capital punishment. In the first work of Idowu (2006) cited, the interest of the author is to critically respond to as well as counter the belief that there is absence of African jurisprudence, while the aim of his second work (Idowu 2009) is to advance the view that there should be a cultural dimension to the understanding of jurisprudence. For Balogun (2007), the focus of interest is on how to arrive at an African concept of law. None of these works seems to have any deeply 
theoretical or practical interest in the exploration of African metaphysical epistemology in relation to legal justice in contemporary Africa.

However, a systematic articulation of the relevance of African metaphysical epistemology to legal justice in post-colonial Africa constitutes the significance of the present study. Although Balogun (2007) refers to something of that nature in passing in the latter part of his work, he does not systematically develop and explain how African metaphysical epistemology could be properly institutionalised to serve the course of legal justice in contemporary Africa: the present article attempts to fill this gap.

Being a term of general application, African epistemology encompasses, according to Martins (2008, 210), quoting N'Sengha (2005, 39-44), four basic ways of knowing: divination, revelation, intuition, and reason which can be separated into the categories of supernatural, natural and paranormal. Thus one could simply state that African epistemology is a composite of both metaphysical and non-metaphysical modes of knowing. Laying emphasis on the metaphysical aspect, though he renders it as being constitutive of the whole of African epistemology, Sentiwali (2008, pars. 5 \& 8) notes the degree of spirituality that has characterized African epistemology. He states that African epistemology placed great emphasis on spirituality, that is, an understanding of the world through a spiritual source. However, there is some conceptual blurriness in Sentiwali (2008) in not clearly distinguishing between African epistemology and African metaphysical epistemology.

The present article focuses on African metaphysical epistemology as defined earlier, rather than on African epistemology as a whole. For purposes of further clarification, one could state that African epistemology is the totality of the modes of knowing within the African world, such as elders' consultation (given that African elders / sages are taken to be repositories of wisdom), sense-experience (given that the elders consulted usually rely on their past social experiences as the basis of their epistemic capacity), reason (given that the African elders/sages reflect on social realities), and spirituality (the metaphysical aspect of African epistemology), among others. 
However, African metaphysical epistemology is that part of African theory of knowledge that lays emphasis on the spiritual modes of knowing empirically hidden facts about the present or the future world. For example, the Ifa oracle in Yoruba culture, a metaphysical form of knowing, may be consulted in order to unravel why a given person behaves abnormally in an attempt to find a cure for him / her after orthodox medical expertise has failed to discover the source of the ailment as well as its cure. In the present context, the epistemic-metaphysical resource of the Ifa oracle, for example, could be properly harnessed and formally harmonised with the empiricist-positivist thinking in the justice system of Nigeria. Similar traditional methods of epistemic value are abundant among other ethnic groups in Nigeria that could be similarly utilised, and the same is true of many other African societies.

There are different modes of knowing that could be justifiably subsumed within what is generally referred to here as African metaphysical epistemology. The wide range of manifestations may include the act of using an altered mental state in order to see and know about the well being of family members and friends living in distant places, which is practiced by the Shaman of the San of South Africa (see Lewis-Williams et. al. 2004, 91); the act of peering into a clay pot filled with virgin water in order to view and know about activities conducted in distant places, practiced by the elderly of the Dagara people (see Malidoma 1994, 25); the consultation with the Ayelala priest/priestess, who, deriving information from the Ayelala goddess, identifies and exposes the culprit of a covert crime without exerting any physical pressure on him/her, among others. A reliable source puts the latter metaphysical process of truthdiscovery thus:

In the event of a crime secretly committed, all the suspects are brought before the Ayelala shrine to swear one after other, holding a specific object in their left hand. After the swearing, the Ayelala priest/priestess leaves the suspects for a while to see the outcome of the exercise. If the real offender is among those who have sworn, then only the offender would compulsorily confess, without being physically forced to do so ... Or, all the suspects are brought before the shrine and given omi Ayelala to drink and thereafter asked to go home. If the offender is among those who have drunk the Omi Ayelala he would start swelling mysteriously and when this becomes unbearable to him, he would 
compulsorily confess to the crime, without being physically impelled to talk. ${ }^{2}$

In the foregoing process, which is usually conducted in some areas of the southwestern parts of Nigeria, for example, it is apparent that the epistemic exercise of truth-discovery has some obvious merit. First, the trickery of the offender may not help him/her to hide his/her involvement in the offence, since potent metaphysical means are deployed to unravel the true identity of the offender. However, if one were to rely on the empiricist-positivist legal reasoning, the offence may not be ascribed to a given offender if there is no physically demonstrable causal connection between the offence and the suspected person, and the offender may thereby go unpunished. It is therefore both theoretically and practically possible for $\mathrm{X}$ to commit an offence against $\mathrm{Y}$ and go unpunished if $\mathrm{Y}$ is unable (perhaps out of incompetence, or due to the brilliance of the defence counsel of $\mathrm{X}$, or the incompetence/connivance of the police in making a proper case) to prove that there is a physically demonstrable causal connection between the injury suffered by the latter and the action of the former.

Thus lack of proof may not imply innocence from legal offence, contrary to empiricist-positivist legal reasoning. In fact, excessive reliance on lack of proof as tantamount to innocence in empiricist-positivist legal reasoning involves the fallacy of argumentum ad ignorantiam (appeal to ignorance). The fallacy proceeds from the erroneous belief that a statement is true because it has not been proved false, or that it is false because it has not been proved true. That a statement has not been proved true or false may really have nothing to do with its actual truth or falsity. Rather, it may have to do more with the incompetence of those who want to prove its truth or falsity.

Similarly, evidence may sometimes be 'manufactured' to prove the guilt of an otherwise innocent person. Thus even correlation may not prove causation, and this is a major weakness of empiricist-positivist legal reasoning. In addition, it could be argued that legal pronouncement resulting from empiricist-positivist legal reasoning may not actually reflect guilt or innocence. Larry Laudan (2006) affirms this:

\footnotetext{
${ }^{2}$ Conversations with the daughter and assistant of the Oba Ayelela of Igode, no 7, Itunlosi Street, Igode, Shagamu, Local Government Area, Ogun State, Nigeria, on 15 ${ }^{\text {th }}$ April, 2010.
} 
... one often hears it said ... that the accused "is innocent until proven guilty" as if the pronouncing of the verdict somehow created the facts of the crime. If it were correct that only a guilty verdict or guilty plea could render someone guilty, then there could be no false acquittals, for it would make no sense to say, as the phrase "false acquittal" implies, that a jury acquitted someone who is actually guilty. Since such locutions make perfect sense, we must reject the notion that a verdict somehow creates guilt and innocence (Laudan 2006, 11; emphases in the original).

All these unfavourable possibilities clearly define the limitations of the dominant empiricist-positivist legal reasoning in the post-colonial African state. In addition, they amply justify the significance of having a reliable epistemic methodology of truth-seeking in the legal theory and practice of any society. If there is no possibility of knowing the truth as to whether or not a crime has been committed resulting in some harm, the truth of who the actual offender is, the truth of who has been actually wronged/ harmed, the possibility of witnessing a miscarriage of legal justice is high.

At this point, one fundamental question still remains: what is the relevance of metaphysical epistemology to legal theory and practice in Africa? We must bear in mind that if it is to be effective, the legal theory and practice of a society ought to recognize and reflect the specificities of that society. This fact constitutes the pragmatic significance of the core recommendation of this study. African metaphysical epistemology recognizes, addresses and therefore complements the limitations of the Western empiricist-positivist legal reasoning in post-colonial African societies.

Many Africans subscribe to the belief that the concept of being is admissible with regard to both the material and the non-material, and that neither is reducible to the other. On the other hand, being an outcrop of the Western metaphysical theory of materialism, both legal empiricism and positivism do not subscribe to the noted African belief. According to Ekanola, there is sufficient proof that traditionally, many, if not all Africans uphold a dualistic conception of reality: they see existence as partly physical and partly spiritual, and also believe in their interrelationship (Ekanola 2006, 75-76). Abimbola (2006) concurs with Ekanola thus: 
... Yoruba religion divides the cosmos into two realms: the spiritual world and the natural world. The spiritual world is the abode of spiritual forces, such as Olodumare (the Yoruba High "Deity"), the Orisa (all the Yoruba divinities), the Ajogun (anti-gods or the malevolent supernatural powers), the Aje (who are translated inadequately into English as "witches") and the ancestors. The natural world is composed of humans, animals and plants. Spiritual beings visit the natural world regularly, and through divination, sacrifice and spirit possession, natural beings can also partake in the spiritual world occasionally. The spiritual and natural worlds are, therefore, interdependent (Abimbola 2006, 52).

As a result of the close relationship between the physical world and the world of spirit beings in African cosmology and ontology, African metaphysical epistemology holds that truth-finding in the administration of legal justice ought to go beyond the physical realm. Consequently, it is able to unravel the true identities of those involved in criminalities that are metaphysically induced, such as the killing of $\mathrm{Y}$ by $\mathrm{X}$ through incantations or other potent metaphysical means, which the empiricist-positivist legal reasoning would find too difficult, or even totally impossible, to unearth. It is also effective in unravelling the true identities of those involved in various criminalities that are usually conducted in high secrecy, such as the killing of political personalities rampant in post-colonial African societies. In fact, African metaphysical epistemology has been found to be effective by the genuine practitioners of it, wherever they are located in Africa, as well as by those who patronize their services. Consequently, we propose that African metaphysical epistemology be recognised in the constitutions of the various African countries within the framework of legal justice.

To negate our first position above about truth-discovery involving metaphysically induced criminalities, it could be argued that the position could easily be dismissed by the contemporary, science-oriented mind. However, we have three counter-theses to this sceptist-scientist objection, namely, logical inconsistency, epistemic incompetence and epistemic injustice.

First, the view of the sceptist-scientist is inconsequential here because he/she is mainly familiar with and concerned about the empirical realm. As such, his/her epistemic claims are only worthy of serious consideration if they are statements with empirical contents, within empirical contexts. Here, we explicitly acknowledge that 
some statements may have empirical contents within empirical contexts. For example, $\mathrm{X}$ killed $\mathrm{Y}$ (the empirical context of killing) and $\mathrm{Z}$ says that he/she saw $\mathrm{X}$ do it (the statement with empirical content about the empirical context), and $\mathrm{Z}$ is generally a trustworthy moral agent. However, some other statements may have trans-empirical contents within empirical contexts. For example, $\mathrm{Z}$ killed Y (the empirical context of killing), and $\mathrm{Z}$ unambiguously confesses that he/she did it through metaphysical means (the statement with trans-empirical content about the empirical context), and $\mathrm{Z}$ was tested and found to be mentally composed when he/she committed the murder, and still so when he/she makes the confession. Now, if one were to draw on the foregoing, one could rightly state that if the sceptist-scientist is to be logically consistent, he/she should not meddle with what is trans-empirical because to do so would be tantamount to being logically inconsistent.

Second, apart from being logically inconsistent, if the sceptist-scientist were to meddle with what is trans-empirical, he/she could also be accused of going beyond what his/her epistemic orientation could possibly support. As such, we would not be obligated to accept his/her claims about trans-empirical reality because he/she is epistemically incompetent as far as such reality is concerned.

Third, one could also reasonably argue that denying any relevance to African metaphysical epistemologists in the present context, without first subjecting them to critical evaluation in this regard, is tantamount to committing an epistemic injustice against them $a b$ initio. An epistemic injustice is committed against any rational person if the value of truth is uncritically or prejudicially denied of his/her claims to knowledge $a b$ initio, or if the property of falsity is uncritically or prejudicially ascribed to his/her claims to knowledge ab initio (see, for example, Fricker 2007). Reflectively, one could state that the principle of epistemic justice requires, among others, that (i) rational claims to knowledge ought not to be uncritically or prejudicially dismissed from the outset, and (ii) rational claimers of knowledge ought to be given ample opportunity to demonstrate their claims to knowledge.

Even if the three counter-theses above were accepted, an objector could still contend that the practitioners of African metaphysical epistemology, by asserting the efficacy of their methodology, infract the principle of natural justice that no one ought to sit as 
judge in his/her own case. However, the principle of natural justice, if it applies here to the practitioners of African metaphysical epistemology, is violated in much the same way by an empiricist-positivist legal practitioner who claims that his/her empiricist-positivist legal reasoning is more effective than any other alternative. As in the case of the claim of the practitioners of African metaphysical epistemology, an empiricist-positivist legal practitioner is also acting as a judge in his/her own case. Thus if the former claim is to be rejected on this account, the latter one also stands dismissed on the same account, if we really want to be consistent.

After advancing the counter-theses above, perhaps a way to resolve the contextual issue is to argue that we should not solely judge the efficacy of African metaphysical epistemology on the basis of the claim of the practitioners, or its inefficacy on the basis of the counter-claim by a person of empiricist-positivist orientation. Rather, a pragmatic approach is to tentatively embrace African metaphysical epistemology and deploy it in legal practice with a view to determining its effectiveness or ineffectiveness.

How, then, could African metaphysical epistemology be tentatively embraced in the legal system of a post-colonial African state? Below we offer three suggestions.

First, associations of practitioners of traditional African epistemology within the postcolonial African state should identify from among themselves those that are tried-andtrue and commend them to the judicial arm of government.

Second, the judicial arm of government should absorb those tested hands from among traditional African metaphysical epistemologists and equip them with requisite skills to enable them to fit into the established system of legal justice. A special body should be created within the judiciary to be responsible for the training and effective operations, as well as for the welfare of those practitioners so absorbed. However, an objector could raise the challenge of reconciling the work of Western-trained legal professionals whose orientation is empiricist-positivist with the task of training these traditional African specialists. Nevertheless, this challenge can be successfully confronted: the people with an empiricist-positivist orientation claim that they deal with hard facts, so to speak. Thus if they were to be consistent, they could not 
possibly deny the hard fact of the general epistemic inability of their orientation to access and understand extra-sensible or trans-empirical reality, or the efficacy of the services of the practitioners of African metaphysical epistemology as well as the causal relationship between the material and the non-material worlds. This obvious orientation deficit can be corrected if those who subscribe to the empiricist-positivist orientation are truly interested in advancing their epistemic frontiers. Nevertheless, they could only address this deficit by embracing the proposed African metaphysical epistemology.

Thus one could aver that African metaphysical epistemology complements, rather than undermines, the epistemic capacity of the Western empiricist-positivist orientation. In fact, the point of the alleged undermining of the empiricist-positivist orientation through the African metaphysical epistemology does not arise at all, given that the term 'undermining' essentially means watering down something, that is, making it less powerful. An official adoption of the African metaphysical epistemology to complement the empiricist-positivist orientation in the justice system in Africa strengthens the efficacy of the latter, given that it extends its truth-seeking function beyond the material realm.

Although we have so far drawn more on the facts from Nigeria to support our position, this does not mean that there are no facts from other countries in Africa to further bolster our argument. In Kenya, for example, the Njuri Ncheke Council, among the Ameru Community, which initially operated as the traditional judicial system on the basis of wisdom, discipline, knowledge and experience of the Ameru history and culture, still occupies a crucial niche among the Community, especially with regard to peace-building through conflict resolution and reconciliation (see Kamwaria et. al. 2015, 44).

Third, since the legislative institution of the contemporary African state is composed of elected representatives of the people, it should make a law to support the laudable project of incorporating African metaphysical epistemology into the legal system.

In our view, if all the foregoing and other requisite measures were taken, there would be a balanced and effective legal justice system that would reflect the peculiarities of 
African societies, thereby highlighting the relevance of specific aspects of our traditional practices to the development of the justice system in post-colonial Africa.

However, there are some criticisms that might be raised against the proposal of the present work. It might be argued that if empirical-positivist legal reasoning is to be rejected in the establishment of criminal wrongdoing, it must be rejected as a mode of reasoning altogether, and would therefore have to be replaced (it could not simply be complemented, because they are incompatible) by a metaphysical epistemology in all areas of reasoning, including science, technology, business practice and everything else. $^{3}$ This counter-argument fundamentally errs in the sense that a total rejection of empirical-positivist reasoning in the legal system is not canvassed by the present study, given its own merit mentioned earlier; the article only proposes that the empiricist-positivist reasoning be complemented by African metaphysical epistemology. There is nothing in the present experience in Africa (except, perhaps, the imposed Western ideological hypocrisy that strictly dichotomizes the empirical and the non-empirical) that strongly indicates that the two modes of reasoning could not be complementary if properly harmonised in practice, even though they are incompatible in theory from a Western perspective. Nevertheless, we are not really concerned with the Western perspective here; instead, we are submitting a proposal from an African perspective.

Furthermore, an objector might assert that the knowledge offered by African metaphysical epistemology is a kind of privileged (restricted) knowledge: it is not open to verification by all, that is, it is not something objective or even intersubjective, ${ }^{4}$ and this obvious weakness of the present proposal is popularly taken to be the strength of the empiricist-positivist procedure. Under close scrutiny, however, it becomes clear that this criticism also applies to the empiricist-positivist procedure. Strictly speaking, with regard to objectivity, we could only reasonably claim a relative, but not absolute, strength for the empiricist-positivist procedure for truthfinding in legal justice. The fact is that there is nothing given to the human person, not even sense-experience (the foundation of the empiricist-positivist procedure), that

${ }^{3}$ This point was specifically raised by one of the earlier reviewers of this work.

${ }^{4}$ This was also noted by yet another reviewer of the work whom we thank for this important point. 
could provide such an absolute knowledge that is objectively open to all in an identical way. The point is that any empirical evidence that is tendered in a court of law does not speak for itself. Actually, legal minds look at it, interpret it, and speak from or through the interpretation of it, and this is where the problem of objectivity emerges. In a court of law, the prosecution and the defence counsels may see the same empirical evidence and, nonetheless, make different inferences from their perceptions. If the empirical evidence were such objectively open to them in a similar way, these different interpretations would not arise.

The famous Shakespearean play, The Merchant of Venice, amply demonstrates a version of the problem of objectivity in the empiricist-positivist legal reasoning. In the work, there was only one bond that specified 'a pound of flesh,' which Shylock, the Jewish merchant, was to cut off Antonio, should the latter fail to pay at the appointed time the money earlier borrowed from the former, on account of Bassanio. The bond was duly signed by Shylock and Antonio. When Antonio failed to repay Shylock at the appointed time, Shylock demanded for nothing else except what was specifically worded in the bond. When the case was brought to a court of law, the said bond was read and strictly interpreted in a way by Portia, a lawyer, to save the life of Antonio, while Shylock also strictly interpreted it in another way to legally support and carry out his sinister motive of killing Antonio in the process of cutting off a pound of flesh. Some critics might be quick to state that this is simply fiction; but it is fiction that depicts what actually obtains in empiricist-positivist legal reasoning.

We do not suggest in any way that our proposal is infallible: actually, nothing in the world of the human person is. The modest claim that we are making is simply that there may be some hidden facts that are highly significant to the task of correctly determining a legal case in the post-colonial African state, but which the dominant empiricist-positivist procedure may be unable to unearth because of its undue emphasis on physicalism. In the absence of such facts, there may be a miscarriage of legal justice. Consequently, we propose the methodology of African metaphysical epistemology, which is suited to addressing the problem of inaccessibility of those facts whose nature places them beyond the reach of the empiricist-positivist framework. 
To further bolster our proposal for the adoption of the methodology of African metaphysical epistemology to complement the dominant empiricist-positivist legal reasoning in post-colonial Africa, there are at least three other significant arguments that could be advanced, as presented below.

\section{(a) Argument from the Promotion of Authentic African Culture in}

\section{Governance}

In the present age of Western cultural globalisation, we should also be concerned with the glocalisation of African values and traditions, that is, the conscientious projection of these values and traditions to the global level by showing forth their relevance to governance in contemporary African societies. By constitutionally approving the African metaphysical epistemology in the administration of legal justice in Africa, we would be show-casing its relevance to the rest of the world: we would be showing the world that the African metaphysical epistemology has something of pragmatic significance to governance on the Continent.

\section{(b) Argument from the Moral Value of Official Recognition of the}

\section{African Metaphysical Epistemologists}

It could also be reasonably argued that showing the pragmatic relevance of the African metaphysical epistemology to the promotion of an effective and balanced system of legal justice in Africa is giving official recognition to its practitioners as significant participants in the building of a stable and vibrant socio-political order on the Continent. We know that African metaphysical epistemologists already function at the traditional level of governance (for example, they are sometimes consulted by king-makers in the choice of kings). The argument here is that they should also be involved in the administration of legal justice within the post-colonial democratic setting in Africa. The moral value of this recognition cannot be over-emphasized, given that recognition necessarily implies a basic attribution of human dignity to the other subject (see Piromalli 2015, 208). 


\section{(c) Argument from Citizenship Theory}

Citizenship theory forms one of the normative foundations of public service ethics. Its central claim is that a public official ought to act in his/her official capacity as a good citizen; and acting as a good citizen entails conducting official business in a way that shows deep commitment to being responsive to fellow citizens - encouraging their participation (in administration), being accountable to them, viewing them as the locus of ultimate administrative loyalty, respecting the dignity of the individual, fostering deep deliberation, and encouraging civic virtue and concern for the common good (see Cooper 2004, 396-397; The Secretariat 1997, 4; Pevkur 2009, Par.16).

Drawing from the citizenship theory of public ethics, it is evident that embracing the services of African metaphysical epistemologists in the administration of legal justice in post-colonial African states achieves at least two objectives: (1) it serves to encourage the practitioners' active participation in the democratic governance of the state, and (2) it presents the leadership of the state as evincing good citizenship.

\section{Conclusion}

In this article, we have made a systematic attempt to critically examine the colonial legacy of empiricist-positivist legal reasoning in the legal theory and practice within the post-colonial African state. Central to our argument is the view that this empiricist-positivist legal reasoning has largely failed to fully dialogue with the holistic understanding of reality within the purview of African cosmology and ontology, since it only approaches reality from the physicalist perspective. The article argues further that this outlook finds it difficult, if not totally impossible, to address metaphysically induced criminalities as well as criminalities perpetrated in high secrecy in contemporary African societies. Lastly, the article recommends the institutionalisation of African metaphysical epistemology within the framework of post-colonial system of legal justice in Africa. This proposal is based on the fact that African metaphysical epistemology accords with the cosmology and ontology of sizeable portions of African populations. It recognizes and addresses the limitations and, therefore, complements the Western empiricist-positivist legal reasoning in postcolonial Africa, just as the latter complements the former because of the latter's relative strength in the area of objectivity. Consequently, if this proposal could be 
accepted and conscientiously implemented, there would be a balanced and effective legal justice system in post-colonial Africa. 


\section{References}

Abimbola, K. 2006. Yoruba Culture: A Philosophical Account. Birmingham: Iroko Academic Publishers.

Austin, J. 1954. The Province of Jurisprudence Determined. New York: Noonday Press.

Badru, R.O. 2008. "A Critique of the Metaphysics of Terrorism: Towards a Progressive Dialogue". Olukoju, Ayodeji and Muyiwa Falaiye eds. Global Understanding in the Age of Terrorism. Lagos: University of Lagos Press, pp.233-245.

Balogun, O.A. 2007. "Towards An African Concept of Law”. African Journal of Legal Theory, vol.1, pp.71-83.

Benthem, J. 1970. Of Laws in General. Hart, H.L.A. ed. London: Anthlone Press.

Comte, A. 2000. The Positive Philosophy of Auguste Comte, With an Introduction by Frederick Harrison. Martineau, Harriet trans. Kitchener: Batoche Books.

Cooper, T.L. 2004. "Big Questions in Administrative Ethics: A Need for Focused, Collaborative Effort". Public Administrative Review, Vol.64 No.4, July/August 2004, pp.395-407.

Dickson, J. 2012. "Legal Positivism: Contemporary Debates". Marmor, Andrei ed. The Routledge Companion to the Philosophy of Law. New York: Taylor and Francis Group, pp.48-64.

Ekanola, A.B. 2006. "Metaphysical Issues in African Philosophy". Oladipo, Olusegun ed. Core Issues in African Philosophy. Ibadan: Hope Publications, pp.74-89.

Fricker, M. 2007. Epistemic Injustice: Power and the Ethics of Knowing. Oxford: Oxford University Press.

Greenawalt, K. 1996.“Too Thin and Too Rich: Distinguishing Features of Legal Positivism”. George, Robert P. ed. The Autonomy of Law: Essays on Legal Positivism. Oxford: Clarendon Press, pp.1-13.

Harris, J.W. 1997. Legal Philosophies, $2^{\text {nd }}$ Edition. London: Butterworth.

Hegel, G.F.W. 1824a (1953). Reason in History: A General Introduction to the Philosophy of History. New York: Liberal Arts Press.

--. 1824b (1956). The Philosophy of History. New York: Dover Publications.

Hobbes, T. 1968. Leviathan. Macpherson, C.B. ed. Harmondsworth: Penguin.

Hume, D. 1854. Of National Characters: The Philosophical Works of David Hume. Including all the essays, and exhibiting the more important alterations and corrections in the successive editions published by the author. V.III, Boston: Little Brown and Company.

Idowu, W. 2005. "Scepticism, Racism and African Jurisprudence". Quest: An African Journal of Philosophy, Vol.XVII, pp.63-90.

--. 2006. "Against the Sceptical Argument, and the Absence Thesis: African Jurisprudence and the Challenge of Positivist Historiography". Journal of Philosophy, Science and Law, vol.6, pp.34-49.

--. 2009. "Rethinking Legal-Constitutional Development in Africa: Beyond the Limits of Legal Positivism, Towards a Cultural Jurisprudence". www.codesria.org/Links?conferences?general.../papers/iowu.pdf (Accessed on

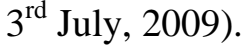


Kamwaria, A.N., R.W. Mugwe, J.M. Kamau, A.J. Githaiga, P.M. Guantai, K.R. Makin and C. Choti. 2015. "Recognizing and Strengthening the Role of the Njuri Ncheke in Devolved Governance in Meru County, Kenya". Journal of Educational Policy and Entrepreneurial Research, Vol.2 No.12, pp.42-47.

Makumba, M.M. 2007. An Introduction to African Philosophy: Past and Present. Nairobi: Paulines Publications, Africa.

Laudan, L. 2006. Truth, Error, and Criminal Law: An Essay in Legal Epistemology. Cambridge: Cambridge University Press.

Lewis-Williams, J.D. and D.G. Pearce. 2004. San Spirituality: Roots Expression, and Social Consequences. Walnut Creek, CA: Altamira Press.

Lyons, D. 1984. Ethics and the Rule of Law. Cambridge: Cambridge University Press. Malidoma, P.S. 1994. Of Water and the Spirit. New York: Penguin.

Martins, D. 2008. "Pan-African Metaphysical Epistemology: A Pentagonal Introduction". The Journal of Pan-African Studies, Vol.2 No.3, pp.209-227.

Nkulu-N Sengha, M. 2005. "African Epistemology". Asante, Molefi and Ama Muzima eds. Encyclopedia of Black Studies. Thousand Oaks, CA: Sage, pp.39-44.

Oke, M. 2007. "An Indigenous Yoruba-African Philosophical Argument Against Capital Punishment". The Journal of Philosophy, Science and Law, vol.7, pp.1-19.

Pevkur, A. 2009. Global and Local Approaches in Public Service Ethics. http://soc.kuleuven.be/io/ethics/paper/Paper\%20ws1_pdf/Aive\%20Pevkur.pdf (Accessed on $17^{\text {th }}$ Sep., 2009).

Piromalli, E. 2015. "Authority and the Struggle for Recognition". International Journal of Philosophical Studies, Vol.23 No.2, pp.205-222.

Sentwali, B.R. 2008. "Epistemology from an Afrocentric Perspective: Enhancing Black Students Consciousness through an Afrocentric Way of Knowing". http://digitalcommons.unl.edu/pocpwi2/20 Accessed on $4^{\text {th }}$ October, 2008).

Stumpf, S.E. 1994. Philosophy: History and Problems, $5^{\text {th }}$ Edition. New York: McGraw-Hill, Inc.

The Secretariat. 1997. Ethics, Professionalism and the Image of the Public Service: A Report of the Secretariat. ST/SG?AC.6/1997/L.3; 6 May 1997. New York: United Nations.

Wacks, R. 2006. Philosophy of Law: A Very Short Introduction. Oxford: Oxford University Press.

Waluchow, W. 1998. "The Many Faces of Positivism”. University of Toronto Law Journal, Vol.48 No.3, pp.387-449.

Wolff, J. 1996. "Hobbes". An Introduction to Political Philosophy. Oxford: Oxford University Press, pp.8-18. 